\title{
Соціальні стереотипи в структурі управлінської діяльності соціальних служб: регіональний аспект
}

\author{
Буканов Г. М., Запорізький національний технічний університет
}

Розглянуто особливості соціальних стереотипів в структурі управлінської діяльності соціальних служб. В структурі управлінської діяльності соціальних служб виокремлено соціальні стереотипи, які можуть бути пов'язані з: 1) особливостями соціального сприйняття (перцептивні стереотипи); 2) раціональною інтерпретацією управлінських фактів (когнітивні стереотипи); 3) соціальними установками стосовно значимих об'єктів управління (диспозиційні стереотипи); 4) ціннісним ставленням до значимих об'єктів управлінського контексту (аксіологічні стереотипи); 5) особливостями соціального оцінювання (оцінні стереотипи); 6) особливостями інформаційної взаємодії (інформаційні стереотипи); 7) особливостями організаційної діяльності (організаційні стереотипи); 8) особливостями технології здійснення управлінських функцій (технологічні стереотипи). Визначено, що особливе значення в управлінській діяльності мають соціальні стереотипи, що пов'язані зі службово-статусними відносинами, мотивацією якісної та ефективної роботи, ставленням до конфліктів в організації і способів їх розв'язання. Представлено результати емпіричного дослідження серед керівників та співробітників соціальних служб на регіональному рівні, на основі яких визначено такі управлінські стереотипи: сприйняття керівника соціальної служби («технократ» чи «гуманітарій»), мотиваційні стереотипи уникнення і досягнення, позиційні стереотипи активно-конструктивного ставлення до конфліктів і їх врегулювання.

Ключові слова: соціальне управління; управлінський стереотип; службово-статусні відносини; мотивація; конфлікт

\section{Social stereotypes in the structure of management of social services: regional aspect}

\section{Bukanov G. M., Zaporozhye National Technical University}

The article considers the features of social stereotypes in the structure of the management of social services. The purpose of the study is to identify the features of social stereotypes in the structure of the management of social services at the regional level. In social services management structure, social stereotypes act as stable, stable notions about social actors, situations and behavior of people or social groups in accordance with accepted norms of culture, social environment, national traditions, professional environment. In the structure of the management of social services, social stereotypes are identified which may be related to: 1) the peculiarities of social perception (perceptual stereotypes); 2 ) rational interpretation of managerial facts (cognitive stereotypes); 3) social attitudes towards meaningful control objects (dispositive stereotypes). ) value relation to significant objects of the managerial context (axiological stereotypes) 5) peculiarities of social assessment (estimated stereotypes) 6) special features and interaction is information (Clearing stereotypes) 7) Features orhanyzatsyonnoy activities (Organizational stereotypes) 8) Features Implementation upravlencheskyh technology functions (Technological stereotypes). A sociological survey of managers and employees of the Zaporizhzhya Regional Center for Social Services for the family, children and youth and its structural units in the Zaporizhzhia Oblast (September-October 2017, $\mathrm{n}=200$, of which 50 respondents - heads of different units and 150 respondents - employees of these divisions). The purpose of the study was to analyze stereotypes in the structure of management relations in the organization. As the main parameters and indicators of research, we have identified: 1) service-status relationships: the style of management in an organization, organizational values in an organization, the level of trust in the system «supervisor-subordinate», assessment of manager's qualities; 2) motivational relations: motives of effective and high-quality work; 3) positional attitudes: perception of conflicts in the organization, sources of conflicts, reaction of leaders to the emergence of conflicts in the collective. Based on the results of empirical research among managers and employees of social services at the regional level, the following management stereotypes have been identified: perceptions of the head of the social service («technocrat» or «humanitarian»), motivational stereotypes of avoidance and achievement, positional stereotypes of active constructive attitude towards conflicts and their settlement.

Keywords: social management; managerial stereotype; service-status relations; motivation; conflict

\section{Социальные стереотипы в структуре управленческой деятельности социальных служб: региональный аспект}

\section{Буканов Г. М., Запорожский национальный технический университет}

Рассмотрены особенности социальных стереотипов в структуре управленческой деятельности социальных служб. В структуре управленческой деятельности социальных служб выделены социальные стереотипы, которые могут быть связаны с: 1) особенностями социального восприятия (перцептивные стереотипы) 2) рациональной интерпретацией управленческих фактов (когнитивные стереотипы) 3) социальными установками по отношению к значимым объектам управления (диспозиционные стереотипы) 4) ценностным отношением к значимым объектам управленческого контекста (аксиологические стереотипы) 5) особенностями социального оценивания 
(оценочные стереотипы) 6) особенностями информационного взаимодействия (информационные стереотипы) 7) особенностями организационной деятельности (организационные стереотипы) 8) особенностями технологии осуществления управленческих функций (технологические стереотипы). Определено, что особое значение в управленческой деятельности имеют социальные стереотипы, связанные со служебно-статусными отношениями, мотивацией качественной и эффективной работы, отношением к конфликтам в организации и способам их решения. Представлены результаты эмпирического исследования среди руководителей и сотрудников социальных служб на региональном уровне, на основе которых определены следующие управленческие стереотипы: восприятие руководителя социальной службы («технократ» или «гуманитарий»), мотивационные стереотипы избегания и достижения, позиционные стереотипы активно-конструктивного отношения к конфликтам и их урегулирования.

Ключевые слова: социальное управление; управленческий стереотип; служебно-статусные отношения; мотивация; конфликт

\section{Постановка проблеми.}

$\mathrm{E}$ фективне управління будь-якою організацією і будь-яким суспільним процесом, незалежно від їх розміру і масштабу, обумовлене в істотній мірі компетентністю керівників, адекватною оцінкою ними управлінських ситуацій і ухваленням оптимальних рішень. Відповідно, при розгляді і рішенні проблеми вдосконалення управлінської діяльності, підвищення культури управління не можна не звернути увагу на стереотипний характер людських дій, особливо в управлінській діяльності соціальних служб. Стереотипи - узагальнені і разом із тим спрощені схеми дій (розумових, оцінних, практичних) досить широко поширені в управлінській, як, втім, і в будь-якій іншій діяльності, роблячи істотний вплив на ії характер та результативність, а в системі закладів із надання соціальних послуг впливають на якість соціального обслуговування населення.

\section{Аналіз досліджень і публікацій.}

Різноманіття концептуальних підходів до дослідження соціальних стереотипів представлено у працях: Т. Адорно, С. Булгакова, М. Вебера, Е. Гідденса, К. Мангейма, Т. Парсонса, П. Сорокіна, К. Юнга. Особливо виділяються праці В. Ліппмана, С. Московічі, Дж. Олпорта, Г. Таджфела - сучасних наукових уявлень, що заклали основи про соціальні стереотипи. Логіко-методологічні аспекти дослідження соціального стереотипу освітлюються в публікаціях: О. Богардус, Л. Боровської, О. Ваніної, А. Донцова і Т. Стефаненко, Н. Ільїнової, В. Ковальова, А. Ослона, Ю. Сорокіна, Б. Шафера, П. Шихирєва, В. Ядова. Значний внесок у міждисциплінарне вивчення соціальних стереотипів внесли: В. Агеєв, А. Угазов, Т. Васильєва, У. Дуаз, В. Ковальов, Ю. Левада, О. Рош, Ж. Тощенко, Ф. Хайєк. Соціологічний підхід до дослідження соціальних стереотипів акцентований у роботах А. Меренкова, В. Ядова. Незважаючи на велику кількість публікацій у даному напрямку, не вивченою є проблема соціальних стереотипів у структурі управлінської діяльності закладів соціальної сфери і соціальних служб зокрема.

Метою дослідження $\epsilon$ визначення особливостей соціальних стереотипів у структурі управлінської діяльності соціальних служб на регіональному рівні.

\section{Виклад основного матеріалу дослідження.}

Розвиток теорії управління в аспекті аналізу співвідношення між інституційними та соціотехнологічними складниками управління системою установ із надання соціальних послуг відбувався завдяки появі низки наукових підходів, які суттєво вплинули і продовжують впливати на формування iii предметної сфери: 1) раціоналістично-бюрократичний підхід, найтиповішими для якого є: школа наукової організації праці (наукового менеджменту) Ф. Тейлора, адміністративна або класична школа управління А. Файоля, теорія структури влади або ідеальної бюрократії М. Вебера; 2) соціально-психологічний підхід, для якого найхарактернішими є: школа людських відносин Е. Мейо, теорія «Х» та «Ү» Д. Мак-Грегора, теорія стилів управління К. Левіна; 3) системно-математичний підхід, який поєднує як класичну і соціально-психологічну школи, так і численні прикладні організаційно-управлінські концепції, теорії та розробки на основі застосування кількісних методів із широким використанням комп'ютерних технологій і програмного організаційного моделювання [11, с. 24]. 3 появою останнього напряму відбувся остаточний перехід у розумінні проблем управління від суто інженерного підходу до соціологічного, в центрі уваги якого перебуває, перш за все, людина в системі управління $з$ іiі потребами, інтересами й цінностями. Внаслідок цього раціоналістичний підхід в теорії управління став поступатися місцем іншому підходу - поведінковому, який грунтується на знаннях фундаментальних положень соціології і психології щодо суб'єктів управлінської діяльності.

Аналіз системи соціальних служб включає визначення іiі структури. Очевидно, що структуру системи соціального обслуговування можна аналізувати, залучаючи різні критерії. У вітчизняних і закордонних публікаціях міцно затвердився так званий «секторний підхід», який виходить із того, що всі організації, які входять до системи соціального обслуговування, умовно можна зарахувати до одного з трьох секторів: державного, комерційного і неприбуткового. При цьому кожен iз секторів виконує як загальні, так і специфічні функції в соціальному обслуговуванні громадян, які потрапили у важкі життєві ситуації.

Поряд із «секторним підходом» до аналізу 
структури системи соціального обслуговування існує також інший підхід, в основі якого лежить ідея виділення не секторів, а рівнів у системі соціального обслуговування. Так, наприклад, Д. Білліс виділяє 5 основних рівнів у рамках системи соціальних служб, на кожному 3 яких розміщаються організації залежно від виконуваних ними функцій:

- «рівень повного охоплення сфери», на якому знаходяться організації, що розробляють політику в сфері соціального обслуговування та створюють концепцію діяльності соціальних служб у масштабах суспільства;

- «рівень повного здійснення служби», на якому розміщуються організації, які здійснюють організацію і управління діяльністю окремих видів соціальних служб;

- «рівень систематичного здійснення служби», на якому розміщуються організації, які несуть відповідальність за здійснення визначених аспектів соціального обслуговування;

- «рівень роботи 3 проблемами як із ситуаціями», на якому знаходяться організації, що безпосередньо займаються наданням підтримки громадянам, які потрапили у важку життєву ситуацію;

- «рівень роботи 3 проблемами як вимогами», на якому розміщуються соціальні служби, що надають в основному інформаційно-консультаційні послуги клієнтам і направляють останніх в інші соціальні служби [10, с.168-170].

Сфера надання соціальних послуг, згідно зі ст. 12 Закону України «Про соціальні послуги», заснована на використанні та розвитку всіх форм власності і складається 3 державного та недержавного секторів. Державний сектор представлений суб'єктами, що надають соціальні послуги і перебувають у державній власності, управління якими здійснюється центральними органами виконавчої влади. До комунального сектору належать установи та заклади комунальної власності, які надають соціальні послуги і перебувають в підпорядкуванні органів місцевого самоврядування. Недержавний сектор представляють громадські, благодійні, релігійні організації та фізичні особи, діяльність яких пов'язана 3 наданням соціальних послуг [4]. На сьогодні слід виділити найбільш поширені державні і комунальні заклади соціального обслуговування в системі соціального захисту населення: територіальні центри соціального обслуговування пенсіонерів та одиноких непрацездатних громадян; центри соціальних служб для молоді; центри зайнятості; центри професійної, медичної та соціальної реабілітації інвалідів; притулки для неповнолітніх; центри соціально-психологічної реабілітації неповнолітніх; будинки нічного перебування бездомних громадян; центри обліку бездомних громадян; соціальні готелі; центри соціальної адаптації; інші заклади [3].

Звернемось до категорії «соціальний стереотип», що вперше до вжитку запровадив В. Ліппман у 1922 р., під яким упорядковані, схематичні, зумовлені культурою образи світу. Сутнісними ознаками були названі неточність, помилковість, інерційність [8]. Далі, в концепції Г. Теджфела, соціальні стереотипи досліджувалися як явище, що сприяє формуванню групової ідентичності [14]. На його думку, стереотипи пов'язані зі сприйняттям людей у термінах групової приналежності. Результатом категоризації виступає акцентування соціальних (групових) розбіжностей між Я і не Я. Таким чином, сутнісна особливість стереотипів їх функціональна роль у взаємодії між Я і не Я. Їм притаманні такі властивості, як динамічність, ситуативність, залежність від контексту між групових відношень, тобто умовою змін стереотипів виступають зміни міжгрупових відносин.

Завдяки дослідженням таких зарубіжних учених, як В. Дуаз, Г. Теджфел, Х. Тріандіс, Д. Кемпбел, а також вітчизняних фахівців В. Агеєва, П. Шихирєва, Т. Стефаненко, Н. Русіної та ін. значно збагатились уявлення про цей феномен. Зазначається, зокрема, що, оскільки в повсякденному житті людина, як правило, не має можливості, часу, повноти інформації для критичного аналізу і самостійного обгрунтування власного уявлення про різноманітні об'єкти соціального середовища, то вона осмислює їх спрощено, стандартно, діє шаблонно, орієнтуючись на принцип «як всі». Такі розхожі уявлення засвоюються на віру і виступають для людини у іiї стосунках $з$ іншими важливою мотивуючою основою.

Наведемо деякі концептуальні визначення цього поняття: «Соціальний стереотип - узагальнена, спрощена та ригідна система уявлень про групи людей, де кожна людина розглядається як носій однакових наборів провідних характеристик, що приписуються кожному члену даної групи, незважаючи на його реальні якості» [1]. У психологічному словнику А. Петровського, М. Ярошевського стереотип вважається ригідною установкою та, у тому разі, коли вона негативна, він призводить до упереджень. Далі автори статті у словнику доходять висновку, що соціальні стереотипи і $є$ упередженнями, тобто ворожою та негативною установкою на окрему групу людей [7]. Сучасна гуманітарна наука процес стереотипізації і власне стереотипи трактує більш широко - як механізм спрощення сприйняття суб'єктом не тільки окремих особистостей і груп, але й різних соціальних явищ і процесів узагалі. Так, І. Кон пише: «...стереотипізація полягає в тому, що складне індивідуальне явище механічно підводять під просту загальну формулу або образ, що характеризує (істинно або хибно) клас таких явищ» $[6$, с. 188$]$.

Отже, в наукових поглядах на роль стереотипів у функціонуванні свідомості людини можна виокремити дві позиції. 3 одного боку, стереотип характеризується ригідністю і консервативністю, має емоційну складову, може провокувати упередження стосовно представників інших груп, блокує творче мислення. 3 іншого боку, стереотипи спрощують 
етапи прийняття рішень, забезпечують послідовність передачі знань і соціального досвіду, таким чином виконують адаптивну функцію.

Порівняльний аналіз концептуальних підходів до дослідження соціальних стереотипів дозволяє виділити і систематизувати основні риси даних феноменів. Незалежно від того, що існують розбіжності в інтерпретації їх різних аспектів, дослідники вважають, що стереотипізація визначається як процес приписування індивідам характеристик на основі їх групової приналежності, а стереотипів - як набору уявлень про характеристики (атрибути) групи людей. Основні властивості стереотипів можуть бути визначені наступним чином: 1) стереотипи виявляються на неусвідомленому рівні; 2) суттєвою ознакою соціального стереотипу є його масовість [5]; 3) ознакою соціального стереотипу виступає його стійкість. Стійкість соціальних стереотипів пов'язана $з$ формуванням стійкої соціальної системи завдяки згуртуванню, інтеграції соціальних груп і утворенню між ними ціннісних типізацій та ідеологем єдиної структурованої соцієтальної спільноти; 4) стереотипи застосовуються для оцінки Своїх та Чужих; 5) стереотипізація виникає тоді, коли при порівняні двох культур чи соціальних груп розбіжності трактуються як полярні протилежності; 6) дослідники (В. Ковальов, Т. Рябова) відзначають, що стереотип є спрощеним засобом репрезентації Іншого, через що формується його один образ $[9$, c. 121]; 7) про соціальний стереотип можна казати лише тоді, коли він поділяється в соціальній спільноті - суб'єкті стереотипізації («консенсус серед членів групи стосовно атрибутів іншої групи», згідно визначенню Д. Тейлора [12]); 8) до числа важливих ознак соціального стереотипу можна зарахувати його амбівалентність (реверсивність) або, за термінологією С. Холла, «стереотипічний дуалізм», тобто «розщеплення» стереотипу на дві протилежні складові [13, с. 258]. Таким чином, суттєвими ознаками соціальних стереотипів є: неусвідомлюваність, масовість, стійкість, спрощеність, аксіологічність, полярність, консенсусність, амбівалентність.

Отже, соціальні стереотипи виступають як стійкі, стабільні уявлення про соціальних акторів, ситуації і поведінку людей або соціальних груп відповідно до прийнятих норм культури, соціального середовища, національних традицій, професійного середовища.

Будь-яка управлінська діяльність як предмет стереотипізації має структуру, в якій потрібно виділяти: по-перше, родові риси, які стосуються будь-якої діяльності, в тому числі управлінської; по-друге, видові ознаки, які стосуються саме управлінської діяльності.

У структурі управлінської діяльності соціальних служб соціальні стереотипи можуть бути пов'язані із: 1) особливостями соціального сприйняття (перцептивні стереотипи); 2) раціональною інтерпретацією управлінських фактів (когнітивні стереотипи); 3) соціальними установками стосовно значимих об'єктів управління (диспозиційні стереотипи); 4) ціннісним ставленням до значимих об'єктів управлінського контексту (аксіологічні стереотипи); 5) особливостями соціального оцінювання (оцінні стереотипи); 6) особливостями інформаційної взаємодії (інформаційні стереотипи); 7) особливостями організаційної діяльності (організаційні стереотипи); 8) особливостями технології здійснення управлінських функцій (технологічні стереотипи).

На цій підставі О. Вервейко розкрив зміст стереотипів на різних етапах управлінського циклу при здійсненні окремих управлінських функцій [2]: 1) постановка управлінської цілі (стереотипи абстрактної цілі, близької цілі, протиставлення цільового і функціонального управління); 2) ресурсне забезпечення ціледосягнення (стереотипи пріоритетності економічних ресурсів, одновимірного розуміння соціальних ресурсів, статичного розуміння соціальних ресурсів); 3) прийняття рішень (стереотипи без альтернативності, «економії», «швидкого результату»); 4) організація (стереотипи екстенсивного розвитку, пріоритету організаційних форм, інверсії, організаційної самодостатності, формальної єдності); 5) мотивація (стереотипи одновимірної мотивації, колективної думки, вертикальної кар'єри); 6) оцінка (стереотипи каузальної атрибуції, проекції, стереотипи «ореолу», «порівняння», самооцінки у вигоду власного Я, недооцінки іншої людини); 7) контроль (стереотипи фетишизації контрольних функцій, орієнтації на контроль, недовіри тощо).

Для виявлення особливостей соціальних стереотипів у структурі управлінської діяльності соціальних служб було проведено соціологічне опитування керівників і співробітників Запорізького

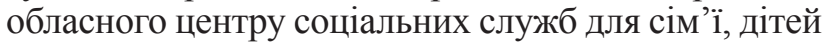
та молоді і його структурних підрозділів у районах Запорізької області (вересень-жовтень 2017 р., $\mathrm{n}=200$, 3 них 50 респондентів - керівники різних підрозділів і 150 респондентів - співробітники цих підрозділів).

Метою дослідження виступив аналіз стереотипів у структурі управлінських відносин в організації. В якості основних параметрів та індикаторів дослідження нами визначено: 1) службово-статусні відносини: стиль управління в організації, організаційні цінності в організації, рівень довіри в системі «керівник-підлеглий», оцінка якостей керівника; 2) мотиваційні відносини: мотиви ефективної і якісної роботи; 3) позиційні відносини: сприйняття конфліктів в організації, джерела конфліктів, реакції керівників на виникнення конфліктів в колективі.

1. Службово-статусні відносини. Респонденти визначають у якості домінуючого стилю управління змішаний (ситуативний) стиль - 39\% і демократичний стиль (32\%), який характеризується децентралізацією влади, колегіальністю прийняття 
управлінських рішень, стимулюванням ініціативи підлеглих, достатністю інформації про перспективи діяльності організації. Причому респонденти визначили в якості найбільш значимих організаційних цінностей наступні: якість виконаної роботи, високий професійний рівень співробітників, досягнення запланованих результатів, співпраця і робота в команді, інтереси клієнтів (замовників), що відповідають орієнтації діяльності організації на якість і результат (отримання прибутку, матеріальний продукт, надання послуги, соціальний ефект тощо).

Стереотипи у відносинах «співробітник керівник» пов'язані значною мірою з відносинами довіри. У початковому визначенні довіра - це віра у те, що взаємні зобов'язання будуть виконані і санкції застосовувати не потрібно. У нашому емпіричному дослідженні довіри акцентувалися два його аспекти: 1) установка респондентів на довіру / недовіру керівникам (підлеглим); 2) джерела можливої недовіри керівникам (підлеглим).

На питання чи «Можна довіряти керівникам?» майже чверть опитаних співробітників (23,3\%) відповіла однозначно не «можна довіряти» і лише 9,8\% респондентів вибрала відповідь «можна цілком довіряти». На думку 8,2\% співробітників «можна частково довіряти». Багато кому важко відповісти $(18,7 \%)$, а значна частина респондентів дала ухильні відповіді - «це залежить від керівника» i «це залежить від обставин». На аналогічне ж питання було запропоновано відповісти керівни- кам, тільки воно вже стосувалося їх ставлення до підлеглих. Дві третини опитаних (66\%) відповіли, що можна довіряти своїм співробітникам, причому 40\% - «можна цілком довіряти», 26\% - «можна частково довіряти». Тільки 4\% вважають, що не можна довіряти співробітникам; інші 30\% дали ухильну відповідь. Таким чином, «кредит довіри» керівників стосовно підлеглих значно вищий, ніж рівень довіри підлеглих своїм керівникам. Помітно виявляються стереотипи недовіри владі і їі носіям. Стереотипи недовіри керівникам підкріплюються тим, як співробітники розуміють причини цього недовір'я: 1) думаю, що взагалі не можна довіряти людям, тим більше керівникам (на це вказали $34,9 \%$ опитаних); 2) положення «керівника» змушує людину бути нещирим $(28,7 \%) ; 3)$ такий висновок я роблю 3 особистого досвіду спілкування 3 керівником (36,4\%). Судячи 3 цих відповідей, стереотипи недовіри керівникам формуються і підкріплюються, по-перше, через вплив більш загальних стереотипів, по-друге, через іррадіацію невдалого особистого досвіду.

В процесі дослідження управлінських стереотипів ставиться також питання про наявність / відсутність стереотипних установок на порівняльну оцінку якостей керівника. Була запропонована 5-бальна оцінна шкала: 5 - якість дуже важлива, 4 - якість достатньо важлива, 3 - якість швидше важливе, чим неважливе, 2 - якість не зовсім важлива, 1 - якість зовсім неважлива. Усереднені результати оцінки приведені на рис. 1.

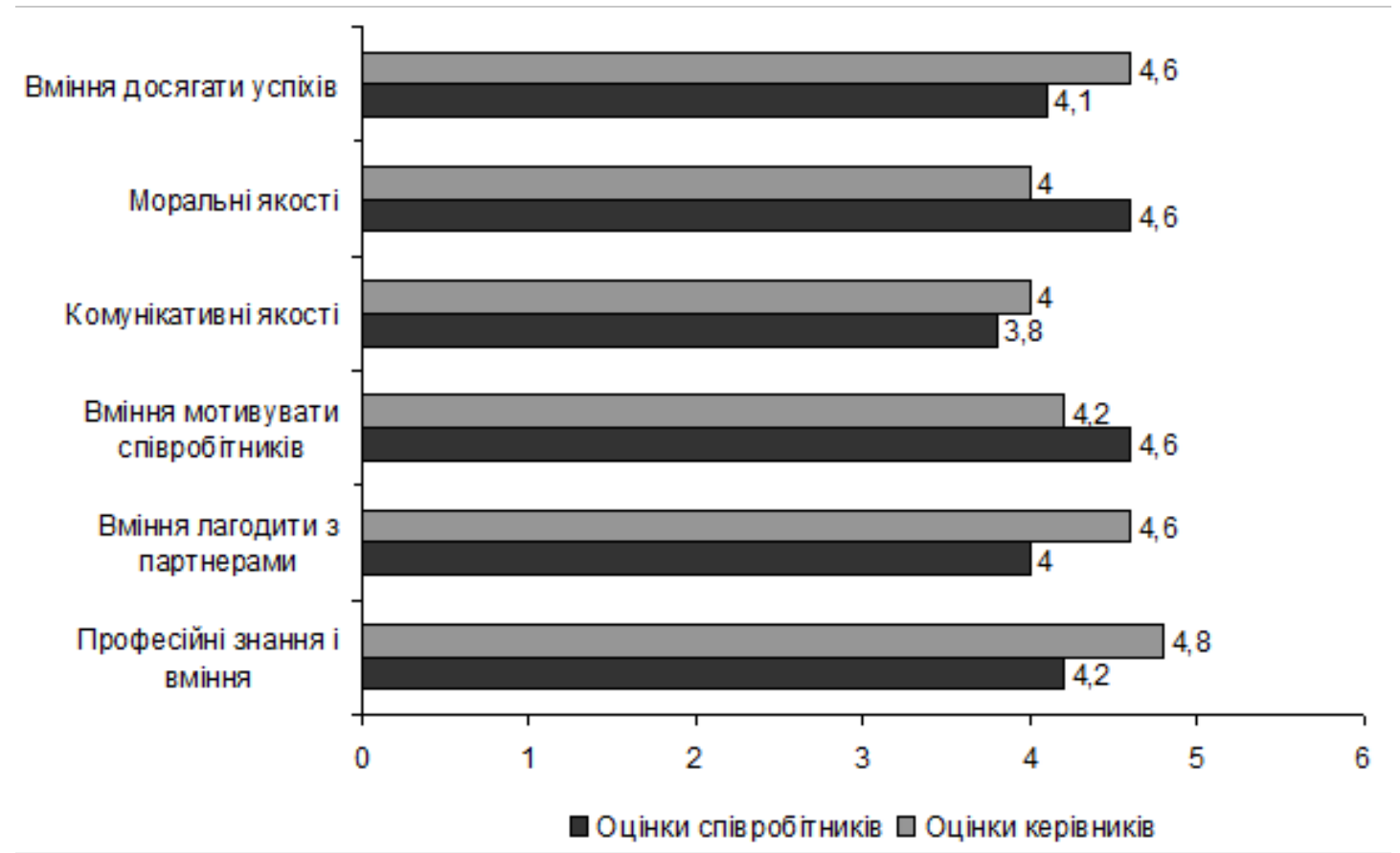

Puc. 1. Оцінка значимих якостей керівника 
Як видно з наведених даних, керівники віддають перевагу професійним якостям керівника, рядові співробітники - моральним і соціальним (уміння мотивувати співробітників) якостям. Логічним буде припущення про те, що на основі таких переваг можуть бути сформовані відповідні стереотипи сприйняття керівників: або стереотип «техно- крата» або стереотип «гуманітарія».

2. Мотиваційні відносини. Службово-статусні стереотипи пов'язані безпосередньо 3 мотиваційними, до аналізу яких ми і переходимо. Як предмет аналізу були вибрані емпіричні інтерпретації мотивів ефективної і якісної роботи (див. рис. 2).

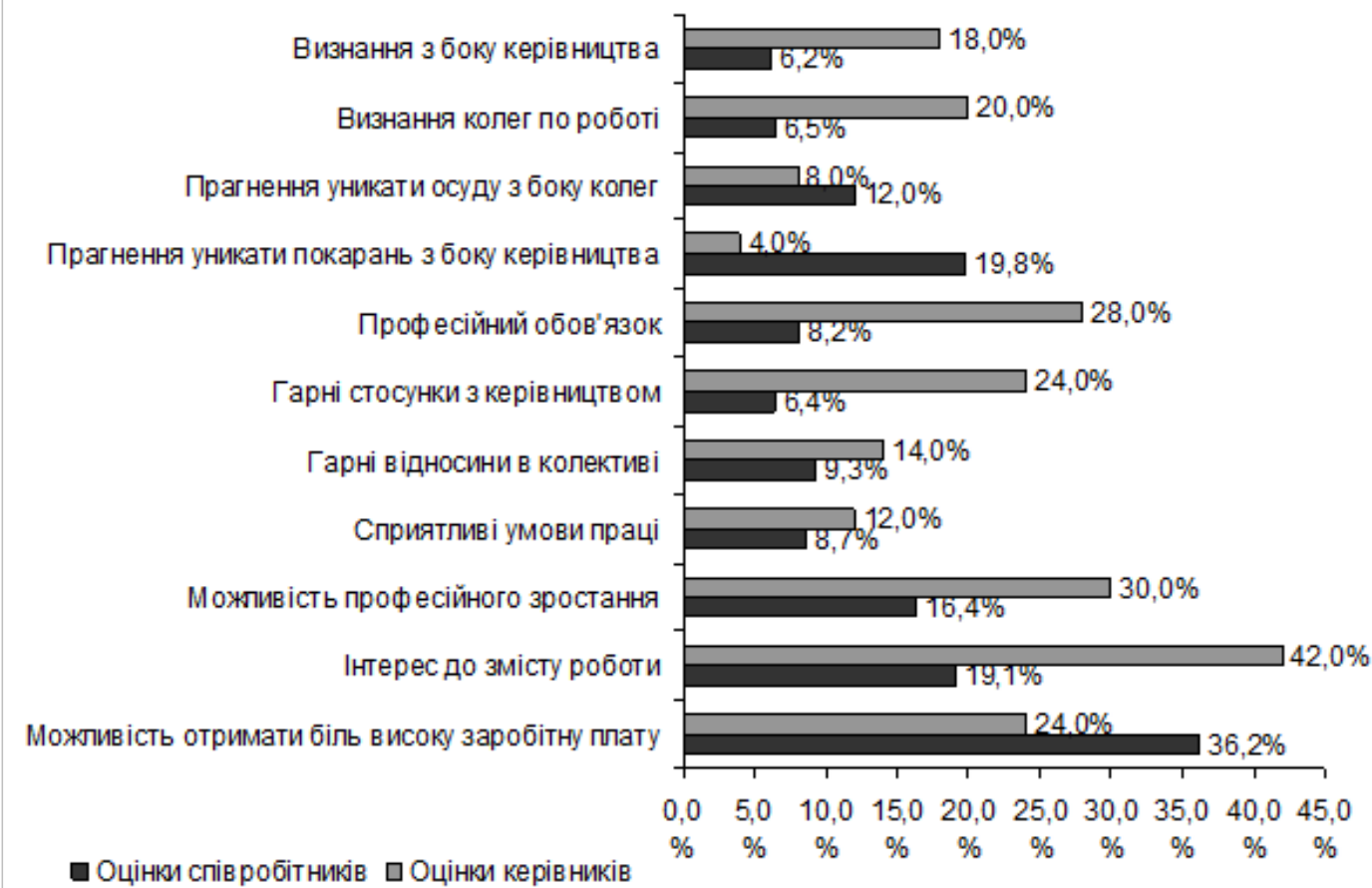

Puc. 2. Мотиви ефективної і якісної роботи

Звертають на себе увагу істотні розбіжності в інтерпретації мотивів успішної роботи. Можна зробити висновок про те, що уявлення рядових співробітників організації про мотивацію стереотипізовані у бік мотивів уникнення, а представлення керівників - у бік мотивів досягнення і збереження.

3. Позиційні відносини. Переходячи до аналізу ще однієї групи управлінських стереотипів - позиційних, відмітимо, що вони стосуються розуміння соціальних конфліктів в організації і механізмів їх урегулювання.

Було поставлене питання про те, яку роль грають конфлікти на роботі. Опитані розділилися на три групи, залежно від оцінки ролі конфліктів на роботі. Перша група утворюється 3 тих, хто вказує на позитивну роль конфліктів. Численніша друга група опитаних, що включає тих, хто пов'язує з конфліктами виключно негативну роль. Порівняно більше їх серед керівників і менше - серед співробітників. Третя група дотримується думки про неоднозначну роль конфліктів. Чисельність таких приблизно однакова серед керівників (в межах 20$22 \%$ і відносно більше - серед рядових співробітників. Таким чином, якщо судити про стереотип сприйняття конфлікту, то він виявляється у вигляді «негативного стереотипу» і виявляється в уявленнях рядових співробітників організації і, особливо, іiі керівників.

Респонденти були опитані також щодо джерела конфліктів на роботі. Їм було запропоновано вказати не більше п'яти причин із переліку, що включає 13 можливих варіантів (див. рис. 3). 


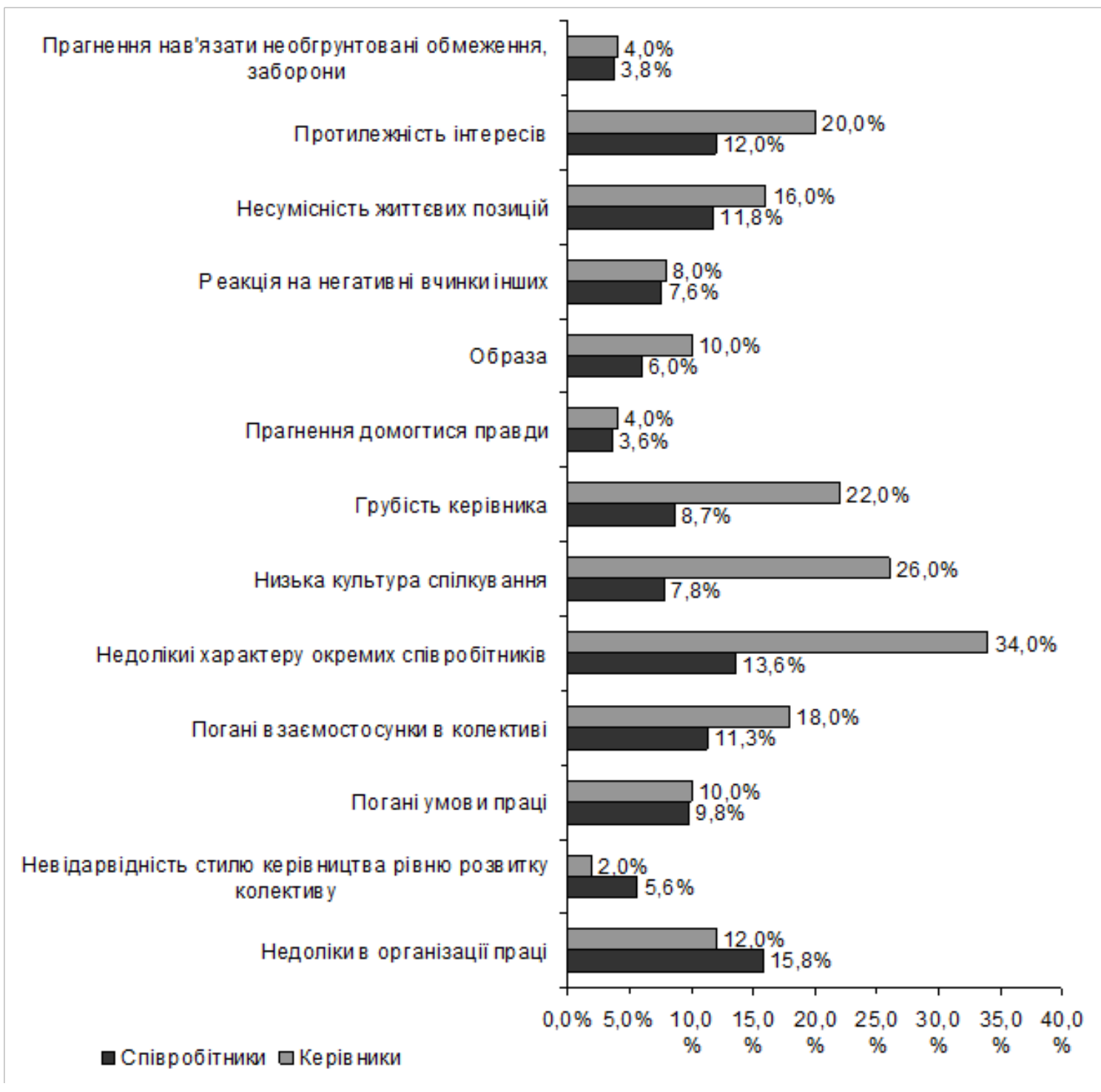

Puc. 3. Основні джерела конфліктів

Конфлікти, як і слід було чекати, викликаються багатьма і різними причинами. Проте, нас у даному випадку цікавлять не самі по собі причини, а їх інтерпретація з боку різних категорій опитаних i, перш за все, керівників і рядових співробітників. Якщо прийняти відповіді рядових співробітників за деякі точки відліку, то стає очевидною схильність керівників до суб'єктивації джерел конфліктів. Вони надають більше значення суб'єктивним чинникам (недоліки характеру окремих співробітників, низька культура спілкування і т. п.), ніж об'єктивним джерелам конфлікту типу «недоліки в організації праці», «погані умови праці» і т. п. Таким чином, можна говорити про стереотип суб'єктивації джерел конфлікту. Цим самим зовсім не заперечується важлива роль суб'єктивних джерел конфлікту, але ця роль вторинна стосовно первинної ролі об'єктивних джерел. Суб'єктивні джерела конфлікту, знаходячись на поверхні поля, прозоріші для розуміння, відразу ж «впадають в очі», через що виникає ілюзія їх домінантності.

Також було виявлено моделі поведінки респондентів у конфліктній ситуації, їх звичайні реакції на конфлікт між співробітниками. Виходячи 3 одержаних соціологічних даних, багато хто 3 опитаних $(33,6 \%)$ не визначився зі своїм ставленням до конфлікту (33,6\%), четверта частина $(25,6 \%)$ намагається допомогти врегулювати конфлікт, 19,1\% прагнуть не помічати конфлікт, 8,7\% надають підтримку одній із конфліктуючих сторін, 4,7\% спостерігають за ходом конфлікту, $2,4 \%$ опитаних чекають моменту, щоб втрутитися в конфлікт. Таким чином, у респондентів переважає пасивна позиція стосовно конфлікту між співробітниками. Якщо зарахувати до тих, хто займає цю позицію тих, кому важко з визначенням свого ставлення до конфлікту, то загальне число «пасивних» складатиме $63,4 \%$, тобто дві третини від загального числа опитаних.

Детальніше досліджувалося ставлення керівників структурних підрозділів до конфлікту між 
співробітниками. Їм було запропоновано відповісти на питання про те, як зазвичай реагують вони на спалахи конфліктів між співробітниками. Переважна більшість керівників $(61,7 \%)$ займають активну позицію стосовно конфліктів між співробітниками, при цьому 18,5\% проявляють тактичну активність, 43,2\% - стратегічну активність, 14,8\% займають помірну позицію і 23,5\% пасивну позицію. Отже, переважання у керівників активної позиції стосовно конфліктів свідчить у даному випадку не тільки про те, що «положення зобов'язує» бути активним, але й про тенденцію активно-конструктивного ставлення до конфліктів i ïx урегулювання, формування культури конфліктної взаємодії.

\section{Висновки.}

Отже, на основі теоретичного аналізу і результатів емпіричного дослідження можна зробити наступні висновки. По-перше, визначено, що соціальні стереотипи виступають як стійкі, стабільні уявлення про соціальних акторів, ситуації і поведінку людей або соціальних груп відповідно до прийнятих норм культури, соціального середовища, національних традицій, професійного середовища. По-друге, в структурі управлінської діяльності соціальних служб виділено такі управлінські стереотипи: перцептивні, когнітивні, диспозиційні, аксіологічні, оцінні, організаційні, технологічні, зміст яких можна розглядати на різних етапах управлінського циклу при здійсненні окремих управлінських функцій. По-третє, визначено стереотипи сприйняття керівника соціальної служби («технократ» чи «гуманітарій»), мотиваційні стереотипи уникнення і досягнення, позиційні стереотипи активно-конструктивного ставлення до конфліктів i їх врегулювання.

\section{БІБІЛІОГРАФІЧНІ ПОСИЛАННЯ}

1. Большой психологический словарь. (Психологические энциклопедии) / Сост. и общ. ред. Б. Г. Мещеряков, В. П. Зинченко. - СПб.: прайм-ЕВРОЗНАК, 2005. - 672 с.

2. Вервейко О. В. Социальные стереотипы в структуре управленческой деятельности: дисс. ... канд. социол. наук: 22.00.08 / О. В. Вервейко. - Белгород, 2015. - 210 с.

3. Дубич К. В. Сучасна система надання соціальних послуг України / К. В. Дубич // Державне управління. - 2015. - № 3.

4. Про соціальні послуги: Закон України // Відомості Верховної Ради України. - 2003. - № 45. - Ст. 358.

5. Ковалев В. В. Проблема социальных стереотипов в зарубежной социологии и психологии / В. В. Ковалев // Гуманитарные и социально-экономические науки. - 2007. - № 1. - С. 16-24.

6. Кон И. С. Психология предрассудка. О социально-психологических корнях этнических предубеждений / И. С. Кон // Новый мир. - 1966. - № 9. - С. 187-205.

7. Краткий психологический словарь / Под общей ред. А. В. Петровского и М. Г. Ярошевского. - М.: Политиздат, 1985. - $431 \mathrm{c.}$

8. Липпман У. Общественное мнение / У. Липпман. - М.: Ин-т Фонда «Общественное мнение», 2004. - 384 с.

9. Рябова Т. Б. Стереотипы и стереотипизация как проблема ген-дерных исследований / Т. Б. Рябова // Личность. Культура. Общество. - 2003. - Т. V. - № 1-2. - С. 120-139.

10. Спікер П. Соціальна політика: теми та підходи / П. Спікер. - Київ: Фенікс, 2000. - 383 с.

11. Швець Д. Є. Моделі управління освітою в структурно-функціональній парадигмі менеджменту та соціології управління / Д. Є. Швець // Гуманітарний вісник ЗДІА. - 2014. - № 56. - С. 23-31.

12. Gardner R. C. Stereotypes as Consensual Beliefs / R. C. Gardner // The psychology of prejudice: The Ontario Symposium. - V. 7. - Hillsdale, N.J., 1994. - 786 p.

13. Hall S. The West and the rest: Discourse and power / Hall S. // Formations of modernity / Hall S., Greben B. (eds.). - Cambridge, 1992. -258 p.

14. Tajfel H. Social stereotypes and social groups / H. Tajfel // Intergroup behavior. - Oxford: Basil Blackwell, 1984. $432 \mathrm{p}$.

\section{REFERENCES}

1. Meshherjakov, B.G., \& Zinchenko, V.P. (Eds.). (2005). Bol'shoj psihologicheskij slovar'. (Psihologicheskie jenciklopedii) [Great psychological dictionary. (Psychological Encyclopedia)]. Saint Petersburg: Prajm-EVROZNAK [in Russian].

2. Vervejko, O.V. (2015). Social'nye stereotipy v strukture upravlencheskoj dejatel'nosti [Social stereotypes in the structure of management activity]. Candidate's thesis. Belgorod [in Russian].

3. Duby`ch, K.V. (2015). Suchasna sy`stema nadannya social’ny`x poslug Ukrayiny [Modern system of providing social services of Ukraine]. Derzhavne upravlinnya [Public administration], 3. [in Ukrainian].

4. Pro social`ni poslugy: Zakon Ukrayiny [The Law of Ukraine «On social services»]. (2003). Vidomosti Verxovnoyi Rady Ukrayiny, 45, art. 358 [in Ukrainian].

5. Kovalev, V.V. (2007). Problema social'nyh stereotipov v zarubezhnoj sociologii i psihologii [The problem of social stereotypes in foreign sociology and psychology]. Gumanitarnye i social'no-jekonomicheskie nauki, 1, 16-24 [in Russian]. 
6. Kon, I.S. (1966). Psihologija predrassudka. O social'no-psihologicheskih kornjah jetnicheskih predubezhdenij [Psychology of prejudice. On the socio-psychological roots of ethnic prejudices]. Novyj mir, 9, 187-205 [in Russian].

7. Petrovskiy, A.V., \& Jaroshevskiy, M.G. (Eds.). (1985). Kratkij psihologicheskij slovar' [Brief psychological dictionary]. Moscow: Politizdat [in Russian].

8. Lippman, U. (2004). Obshhestvennoe mnenie [Public opinion]. Moscow: In-t Fonda «Obshhestvennoe mnenie» [in Russian].

9. Rjabova, T.B. (2003). Stereotipy i stereotipizacija kak problema gendernyh issledovanij [Stereotypes and stereotyping as a problem of gene studies]. Lichnost'. Kul'tura. Obshhestvo, 1-2, 120-139 [in Russian].

10. Spiker, P. (2000). Social 'na polity 'ka: temy` ta pidxody` [Social policy: themes and approaches]. Kyiv: Feniks [in Ukrainian].

11. Shvecz, D.Ye. (2014). Modeli upravlinnya osvitoyu v strukturno-funkcional`nij parady`gmi menedzhmentu ta sociologiyi upravlinnya [Models of education management in the structural-functional paradigm of management and sociology of management]. Gumanitarny j visny k ZDIA, 56, 23-31 [in Ukrainian].

12. Gardner, R.C. (1994). Stereotypes as Consensual Beleifs. The psychology of prejudice: The Ontario Symposium. Hillsdale, N.J.

13. Hall, S., \& Greben, B. (1992). The West and the rest: Discourse and power. Cambridge.

14. Tajfel, H. (1984). Social stereotypes and social groups. Intergroup behavior. Oxford: Basil Blackwell.

\section{Буканов Григорій Миколайович}

Кандидат політичних наук, доцент

Запорізький національний технічний університет

69061, м. Запоріжжя, вул. Жуковського, 64

Bukanov Grigory N.

Candidate of political sciences, associate professor

Zaporozhye National Technical University

64, Zhukovsky Str., 69061, Zaporozhye, Ukraine

ORCID: 0000-0002-5398-5953_Ｅmail: vip.gregorov@ukr.net

Цитування: Буканов Г. М. Соціальні стереотипи в структурі управлінської діяльності соціальних служб: регіональний аспек / Н. В. Дзюба // Науково-теоретичний альманах «Грані». - 2018. - Т. 21. - № 4. C. 56-64.

Citation: Dziuba, N.V. (2018). Sotsialni stereotypy v strukturi upravlinskoi diialnosti sotsialnykh sluzhb: rehionalnyi aspekt [Social stereotypes in the structure of management of social services: regional aspect]. Scientific and theoretical almanac «Grani», 21(4), 56-64. 